\title{
The Effect Of Family And Social Environment On Smoking Behaviour In Adolescence
}

\author{
Zoe Roupa, Professor \\ University of Nicosia, Cyprus \\ Aristidis Vasilopoulos \\ Hellenic Center of Disease Control and Prevention, Greece \\ Chryssi Hatzoglou, Assistant Professor \\ Medical Physiology, University of Thessaly, Greece \\ Konstantinos Gourgoulianis, Professor \\ Pneumonology, Rector of University of Thessaly, Greece \\ Antonios Kefaliakos, $\mathrm{MSc}$, PhD
}

Researcher Assistant TEI of West of Greece, Department of Physiology and Clinical Neurophysiology, School of Nursing, University of Athens, Greece

Enkeleint - Aggelos Mechili, MSc, PhD

Department of Public Health,

School of Nursing, University of Athens, Greece

Olga Archangelidi, PhD Candidate

Farr Institute of Health Informatics, University College London, UK

Emmanouil Mentzakis, Associate Professor

Economics, University of Southampton

Marianna Diomidous, MD, RN, MSC, MBH, PhD

Assistant Professor of Epidemiology, University of Athens, Greece

doi: 10.19044/esj.2016.v12n2p62 URL:http://dx.doi.org/10.19044/esj.2016.v12n2p62

Abstract

Background: Parental and peer smoking are considered major predictors of smoking in adolescence. We investigate the impact of family and social environment and parental anti-smoking socialization on the intensive and extensive margins of smoking for Greek adolescents.

Method and Material: Information on 873 adolescents was collected through a self-reported survey and regression analysis examined associations with five different smoking outcomes (current/lifetime smoking status/intensity and onset). Subgroup analyses and interactions provided further insights.

Results: Prevalence of adolescent smoking is high. Family and peer smoking habits and smoking restrictions at home reduce probability and intensity of smoking. Parental smoking increases probability of current smoking by $5 \%$ 
(95\% CI: 0.01-0.09) as does having all your friends smoking by 30\% (95\% CI: 0.16-0.45). Parental anti-smoking advice delays onset of smoking by 0.76 years (95\% CI: 0.15-1.39) but does not affect current smoking.

Conclusion: Family and social environments play a significant role in preventing or promoting smoking and should be regarded as crucial factors when devising policy to curb adolescent smoking.

Keywords: Adolescent smoking, anti-smoking socialization, parental smoking, peer smoking

\section{Introduction}

With tobacco consumption being the leading cause of preventable death in the world smoking currently remains one of the biggest public health concerns (WHO, 2013). While adult smoking rates in Europe have decreased by about 5\% since 2000 (OECD, 2012) adolescent smoking is reportedly on the rise (Wold et al., 2004). Greece displays one of the highest level of adult smoking in EU with at least 30\% of the adult population smoking daily (OECD, 2012; Vardavas et al., 2007), yet around one in five boys and one in ten girls is found to smoke at least once a week (WHO, 2012) placing Greece below the EU average prevalence rate for girls and just about below for boys (Spyratos et al., 2012).

Despite such lower rates, interventions to prevent adolescent smoking are critical in slowing or halting the upward prevalence trends and increased tobacco related illnesses (Moeini et al., 2012). However, the reasons for the rising trends in adolescent smoking, especially when adult smoking rates are dropping, are not fully understood (Gilman et al., 2009). Three groups of factors have received attention for their influence on adolescent smoking: a) family (parental smoking, number of smokers in the family, parental permissiveness and probable approval), b) peer groups or friends (number of friends who smoke, and academic expectation by friends) and c) individual characteristics (e.g. gender, ethnicity, concerns with body-weight, attitudes to smoking) (Mayhew et al., 2000). Family environment exerts a direct impact on children's psychosomatic development.With family serving as a role model and principal guide for adolescents' future socialization, parents and parental antismoking socialization play an important role in smoking prevention in adolescence. Parental smoking behaviour is a major predictor of early onset of smoking in adolescents (Frech, 2012; Martínez-Hernáez et al., 2012; Sargent et al., 2012). Children experiencing parental smoking are significantly more likely to smoke compared with children of non-smokers (Nelson et al., 2011). According to the literature, having smoker mother increases odds of smoking by 1.7 times, whereas having mother who has ever smoked increases the odds by 3.4 times (Darling and Cumsille, 2003). 
Spyratos et al.(Spyratos et al., 2012) showed that, in Greece, children of smokers or children with siblings who smoke are two times more likely to smoke, compared to children of non-smoking families, while other studies have shown that when both parents quit smoking, children's odds of daily smoking are reduced by 39\% (Bricker et al., 2003). At the same time, a strong co-evolution of adolescents' friendship networks and smoking behaviour has been demonstrated (Mercken et al., 2009).

A recent study found that, peer and parent influences were mostly significant for girls but not for boys (Chassin et al., 1996), something confirmed by Waldron (Waldron, 1991) when examining the association between smoking initiation and friends smoking. In general, girls have been reported to be more susceptible to social influences than boys (SimonsMorton, 2002). Girls tend to have more smoking friends over time, although prevalence of smoking among 15 years olds and age of smoking onset is similar between genders (prevalence: $10.6 \%$ for girls and $9.2 \%$ for boys; onset: 14.2 for girls and 13.8 for boys) (Flay et al., 1998). Ethnicity, affluence, education and parental characteristic further exhibit strong links with smoking (Chassin et al., 1984; Proescholdbell et al., 2000).

Given Greece's status as a high adult smoking prevalence country and its current relatively small (but at risk and growing) adolescent smoking population this study contributes to the literature by focusing on the intensive and extensive margins of smoking behaviour examining differences between current and lifetime, as well as, onset behaviour. Particularly, associations between smoking, parental antismoking socialization and peer/network effects for a sample of 13-18 years old are discussed, while adjusting for a number of confounding factors and characteristics.

\section{Methods and materials \\ Data and study sample}

An anonymous, self-report survey on smoking habits was administered to a stratified random sample of junior high and high schools (i.e. 12-18 year olds) in Central Greece (Lamia - Larissa) during the period $01 / 10 / 2011-02 / 02 / 2012$. The survey was supplemented with a number of structured and semi-structured interviews with high school students. Special abilities schools, church-schools and evening schools (mainly enrolling adults) were excluded from sampling due to generalizability and representativeness concerns. To ensure validity of the questionnaire content, the related Greek and international literature was reviewed, based on research on MEDLINE, EMBASE and CINAHL databases. The self-report questionnaire used in this research included questions on participants' demographics, smoking habits, knowledge and attitudes towards smoking, peers' and family's smoking habits and antismoking socialization. Out of the 
1,000 questionnaires distributed, 873 of them were completed and returned (87\% respond rate). Ethical approval for the survey was granted by the Ministry of Education and the respective Secondary education authorities of the two prefectures sampled.

\section{Smoking outcomes}

Five distinct outcomes of adolescent smoking were examined; a) ever a smoker (Yes / No), b) number of cigarettes smoked in one's life (less or / more than one packet), c) currently a smoker (Yes / No), d) number of cigarettes currently smoked per day (Up to or / more than 1 cig a day) and e) age of first cigarette.

\section{Antismoking socialization and peer effects}

Antismoking socialization was captured by two variables. Whether smoking is allowed at home (ie everywhere or in some / or no places) and how often in the last few months have parents talked to/advised adolescents about smoking (ie never, once or twice, more than three times). Peer-effects were captured by friend's smoking habits and the effect was further broken down to the extent of smoking within the adolescent's friends network.

\section{Confounding factors and covariates}

Analyses of the association between smoking behaviour of adolescents and parental or peer influences were adjusted for a number of covariates and confounding factors, i.e. socio-economic and demographic characteristics (age, gender, school marks, live with parents, pocket money), parental smoking, knowledge of smoking health effects (i.e. advice from professional, acknowledging smoking's health harm) and social-norms (i.e. believe smokers to be more attractive).

\section{Statistical Analysis}

Initially, cross-tabulations and chi-square statistics were used to present the differential antismoking socialization behaviour by parental smoking status. Univariate associations between adolescent current smoking, antismoking socialization and parental smoking were further examined by using chi-square statistics. To assess whether anti-smoking socialization practices were associated with adolescents' smoking, regression analysis was performed. Specifically, logistic regressions were specified for our four binary smoking outcomes, and least squares regression (OLS) for our continuous one.

To further examine the regulating effect of gender and parental influence, subgroup analyses by child gender and parental smoking status 
were performed. Finally, models with interactions between child gender, parental smoking and parental advice on smoking were specified.

For all logistic models, interpretation was carried through marginal effects, which are presented in the tables. Marginal effects were computed as the first derivative (for continuous covariates) or as a discrete change in probability (for the categorical covariates) and were interpreted as percentage changes in the probability. For the OLS model, interpretation was based on the estimation coefficients which indicate a change (in years) in the onset age of smoking. The statistical package Stata 12.1 was used for all analyses.

\section{Descriptive results}

Table 1 presents sample descriptive statistics with the last column of significance showing whether there are statistically significant differences between smoking adolescents and non-smoking adolescents (i.e. columns 4 and 5). Out of 873 respondents, 50\% were boys, $12 \%$ current smokers and $27.7 \%$ ever smokers. Of those who reported that are smokers, 29\% had smoked more than 6 packs of cigarettes in their life. Of the current smokers 14.2\% reported smoking more than 20 cigarettes per day, whereas $46.7 \%$ reported smoking up to one cigarette per day. The mean age of first cigarette was 13.7 years and the mean age of the whole sample 14.9 years. About $50 \%$ of the sample received school marks within the highest bracket, while comparing the marks distribution between smokers and non-smokers large differences were found with non-smoker exhibiting significantly better marks. Similarly, looking at the cohabitation statuses of smoker and nonsmoker adolescents statistical differences were observed, with twice as many smokers living with either the father (4\%) or mother (9\%) alone compared to non-smokers (1.5\% and 5\%, respectively).

\section{Antismoking socialization}

Smoking adolescents appeared to receive approximately €33 more pocket money than non-smokers, tend to more often come from homes that at least one parent smokes (71\%) or from homes with more relaxed rules on whether smoking is allowed in the house. 29\% of smokers report that smoking is allowed everywhere in their house compared to only $12.5 \%$ of non-smokers. Antismoking family advice is similar across child's smoking status although non-smoking kids tend to receive advice more often. On average when parents are smokers, $17 \%$ of the respondents report that smoking is allowed everywhere at home, with the percentage increasing for children that smoke (32\%) and decreasing for non-smoking adolescents (12.9\%) (Table 2). Where neither parent nor children are smokers, adolescents report that smoking is allowed everywhere in the house in $11.2 \%$ 
of the cases, compared to smoker children with non-smoker parents that reached 22.2\%. When parents are smokers and children non-smokers, smoking is allowed only in the balcony or yard in $49 \%$ of the cases, in contrast to both parents and children smokers (25\%). When parents are smokers but offer antismoking advice frequently, children are more often non-smokers (42.4\%) than smokers (33.9\%), whereas when smoking parents offer antismoking advice in one instance, the percentage of smoking adolescents is higher (23.7\%) than that of non-smoking adolescents $(10.3 \%)$ (Table 2).

\section{Peers and attitudes}

A high percentage (61\%) of non-smokers report no smoking friends compared to $10 \%$ of smokers (Table 1). No statistical differences are found in acknowledging smoking's harmful aspect or on whether they have received professional info of smoking harm. However, three times as many smoking adolescents believe smokers to be more attractive compared to nonsmoking adolescents.

\section{Regression analysis results}

According to the results of this study, males have 5\% decreased probability of being current smokers, with $15 \%$ less chances to have smoked more than 1 packet in their lifetime and are 23\% less likely to currently smoke at least 1 cigarette. Adolescents with high grades (17.1-20) have a $34 \%$ and $23 \%$ decreased probability of having ever smoked more than a packet and currently being a smoker, respectively. Age played also an important role, with age increasing the probabilities of being ever or current smokers as well as the number of cigarettes ever smoked (3.7, 3.6\% and $5.2 \%$ respectively)

\section{(Table 3).}

\section{Adolescent smoking and family}

When parents were smokers, children are 5.2\% more likely to currently smoke (Table 3). Additionally, we find an association between having no restrictions in smoking place at home and smoking status in adolescents, with a higher probability of adolescent smoking, when they have smoker parents and no restrictions at home, of $8 \%$ being a current smoker and $28.7 \%$ of having ever smoked more than 1 cigarette (Table S1). We further find that when parents are smokers, frequent anti-smoking advice is associated with a decreased probability of children being ever smokers by $10 \%$, whereas in cases of non-smoking parents, frequent advice is associated with an $81.9 \%$ increased probability of currently smoking more than one cigarette per day (Table S2). 


\section{Adolescent smoking and peers}

The number of smoking friends plays a significant role on smoking status of adolescents. When some peers are smokers, the probability of the respondent being a current smoker is increased by $10 \%$, while when all peers are smokers, the corresponding probability is $30 \%$ and the probability of having ever smoked is 57.9\% (Table 3). Additionally, when all friends are smokers, the age of first cigarette smoked, is lowered by 1.3 years. However, for adolescents with non-smoking parents, in spite of having some smoking friends, the probability of smoking more than one cigarette a day drops by $74.6 \%$ (Table S2) whereas with smoking parents such association is insignificant (Table S1).

\section{Adolescent smoking and knowledge or attitudes}

Acknowledging that smoking is potentially harmful is associated with a decrease in the probability of smoking $>1$ cigarette per day of $45.3 \%$ (Table 3) and 61.9\% (Table S1) when the respondents have smoking parents. When parents are non-smokers, information by professionals decreases the probability of adolescents being current smokers by $6.7 \%$ compared to those with smoking parents whose corresponding effect is insignificant (Table S2). Finally, considering smokers attractive is associated with an $11 \%$ higher probability of ever being smoker (Table 3).

\section{Subgroup analysis}

Higher grades (i.e. between 17.1 and 20) were linked with a decreased probability of ever being or currently being a smoker for both genders (Table S3, Table S4). An association between mothers living at home and a reduced probability (41.5\%) of currently smoking $>1$ cigarette a day was identified for boys but not girls. Restrictions in places to smoke at home significantly reduce probabilities of being current or ever smoker in girls ( $8.7 \%$ and $14 \%$ less likely to be a smoker, respectively), while no such effect is identified for boys. Peers smoking effects are present in both genders, although the association is attenuated for boys as shown in the subgroup analysis. Girls are more prone to comply with professionals' advice compared to boys, with the former showing a 36\% decreased likelihood of smoking more than one cigarette per day. Finally, boys are found to be less affected by attitudes towards smoker attractiveness compared to girls who display an increased probability of currently or ever smoking.

\section{Interactions analysis}

Models with two- and three-way interactions showed limited significance with the overall findings largely comparable. Family advice 
becomes significant when looking at the number of cigarettes ever smoked with its influence more effective in reducing smoking for girls but not boys, while higher probabilities of increased smoking are observed for those with smoker parent who have received advice once/twice.

\section{Discussion}

The present study examines associations of anti-smoking socialization practices, peer/network effects and attitudes towards and knowledge of smoking facts with the intensive and extensive margins of adolescent smoking behaviour for a sample of Greek students.

We confirm past literature where parental smoking and house smoking rules or complete ban of indoor smoking are repeatedly shown to directly influence children's smoking habits (Frech, 2012; Green et al., 1991; Martínez-Hernáez et al., 2012; Petraitis et al., 1995; Sargent et al., 2012). Familial smoking habits expand the habitual nature of smoking for adolescents making it a second nature. Yet, findings on the effectiveness of family anti-smoking advice are mixed (Ertas, 2007; Otten et al., 2008). Similar to past studies, we find that frequent communication between parents and children about smoking is largely a risk factor for adolescents' smoking (Goldade et al., 2012; Huver et al., 2006) with frequency of communication negatively associated with self-efficacy (Fearnow et al., 1998). In contrast, anti-smoking advice is found elsewhere to result in lower risk of smoking for adolescents (Chassin et al., 1996; Fearnow et al., 1998; Goldade et al., 2012) albeit some argue that it is frequency rather quality of communication that deters adolescent from smoking (Otten et al., 2007). Ennett (Ennett et al., 2001) suggest that once adolescents start smoking parents tend to pass antismoking advice more frequently to induce smoking cessation. As such, the timing of communication is essential in the effectiveness of parental advice with advice at later stages of adolescence (Villanti et al., 2011) or following adolescents' experimentation with smoking (Henriksen and Jackson, 1998) having little success. The timing aspect of parental advice is also observed in our results where anti-smoking advice is found to delay the onset of smoking something that is confirmed elsewhere (Jackson and Henriksen, 1997).

While the family effect is strong, the tendency towards smoking is heavily affected by peer behaviour both in past literature and in the present study. The number of smoking friends plays a consistently significant role to the smoking status of adolescents (Friedman et al., 1985). Studies show that children from smoking family environment and with friends who smoke have higher chances to smoke (Clark et al., 1999; Kyrlesi et al., 2007). We further confirm past literature that the presence of non-smoking families or strong parental disapproval of smoking mediates peer effects (Sargent and Dalton, 2001). 
Mothers are generally more positive about anti-smoking socialization practices in preventing smoking. An explanation may be the stronger everyday interactions that mothers better insight into events occurring in the family and more control over daily parenting matters (Amos and Bostock, 2007). However, the strong association we find between presence of mothers at home and reduced current smoking intensity for boys (not for girls) might be explained by bonds developed between mothers and sons during early childhood. In general, the way adolescents are approached by parents in their daily lives has significant effects. Even though school performance is associated with lower smoking, pressure regarding school performance has been found to considerably increase the risk of smoking among students of both sexes (Martínez-Hernáez et al., 2012).

However, the correlational nature of our findings is acknowledged. The lack of causality in our analysis often makes interpretation problematic. For instance, the finding of increased smoking along with increased antismoking advice can simply be a result of increased advice given towards adolescents that already smoke. In fact, Avenevoli and Merikangas (Avenevoli and Merikangas, 2003) found a bi-directional relationship between parents-child communication/rules and smoking habits, whereby adolescent smoking at baseline could be predicted, by parent-child communication and vice versa (Goldade et al., 2012). Similarly, although smoking behaviour is often found to be correlated among friends and subsequently attributed to be peer effects, it is possible that it is a result of selection of the adolescent into a group that already smokes (i.e. one chooses friends with similar habits rather than ones' friends push him towards a specific habit).

\section{Conclusion}

The intensive and extensive margins of current and lifetime smoking habits are examined for a sample of Greek youths. The prevalence of adolescent smoking is high and we find that family and peer smoking habits and smoking restrictions at home reduces probability and intensity of smoking, while parental anti-smoking advice has mixed effects. In conclusion, encouragement and adoption of anti-smoking socialization policies can form part of future public health campaigns against onset of adolescent smoking but may not be effective in reducing prevalence of current youth smoking. Although our sensitivity analyses have provided an in depth picture of the associations between adolescent smoking and antismoking socialization, parental and peer effects further research needs to focus on identifying causal pathways. 


\section{References:}

Amos, A., Bostock, Y., 2007. Young people, smoking and gender-a qualitative exploration. Health Educ. Res. 22, 770-781.

doi:10.1093/her/cyl075

Avenevoli, S., Merikangas, K.R., 2003. Familial influences on adolescent smoking. Addict. Abingdon Engl. 98 Suppl 1, 1-20.

Bricker, J.B., Leroux, B.G., Peterson, A.V., Kealey, K.A., Sarason, I.G., Andersen, M.R., Marek, P.M., 2003. Nine-year prospective relationship between parental smoking cessation and children's daily smoking. Addict. Abingdon Engl. 98, 585-593.

Chassin, L., Presson, C.C., Rose, J.S., Sherman, S.J., 1996. The natural history of cigarette smoking from adolescence to adulthood: demographic predictors of continuity and change. Health Psychol. Off. J. Div. Health Psychol. Am. Psychol. Assoc. 15, 478-484.

Chassin, L., Presson, C.C., Sherman, S.J., 1984. Cognitive and social influence factors in adolescent smoking cessation. Addict. Behav. 9, 383390.

Clark, P.I., Scarisbrick-Hauser, A., Gautam, S.P., Wirk, S.J., 1999. Antitobacco socialization in homes of African-American and white parents, and smoking and nonsmoking parents. J. Adolesc. Health Off. Publ. Soc. Adolesc. Med. 24, 329-339.

Darling, N., Cumsille, P., 2003. Theory, measurement, and methods in the study of family influences on adolescent smoking. Addict. Abingdon Engl. 98 Suppl 1, 21-36.

Ennett, S.T., Bauman, K.E., Foshee, V.A., Pemberton, M., Hicks, K.A., 2001. Parent-Child Communication About Adolescent Tobacco and Alcohol Use: What Do Parents Say and Does It Affect Youth Behavior? J. Marriage Fam. 63, 48-62. doi:10.1111/j.1741-3737.2001.00048.x

Ertas, N., 2007. Factors associated with stages of cigarette smoking among Turkish youth. Eur. J. Public Health 17, 155-161. doi:10.1093/eurpub/ckl095

Fearnow, M., Chassin, L., Presson, C.C., Sherman, S.J., 1998. Determinants of parental attempts to deter their children's cigarette smoking. J. Appl. Dev. Psychol. 19, 453-468. doi:10.1016/S0193-3973(99)80050-1

Flay, B.R., Hu, F.B., Richardson, J., 1998. Psychosocial predictors of different stages of cigarette smoking among high school students. Prev. Med. 27, A9-18.

Frech, A., 2012. Healthy behavior trajectories between adolescence and young adulthood. Adv. Life Course Res. 17, 59-68. doi:10.1016/j.alcr.2012.01.003

Friedman, L.S., Lichtenstein, E., Biglan, A., 1985. Smoking onset among teens: an empirical analysis of initial situations. Addict. Behav. 10, 1-13. 
Gilman, S.E., Rende, R., Boergers, J., Abrams, D.B., Buka, S.L., Clark, M.A., Colby, S.M., Hitsman, B., Kazura, A.N., Lipsitt, L.P., LloydRichardson, E.E., Rogers, M.L., Stanton, C.A., Stroud, L.R., Niaura, R.S., 2009. Parental smoking and adolescent smoking initiation: an intergenerational perspective on tobacco control. Pediatrics 123, e274-281. doi:10.1542/peds.2008-2251

Goldade, K., Choi, K., Bernat, D.H., Klein, E.G., Okuyemi, K.S., Forster, J., 2012. Multilevel predictors of smoking initiation among adolescents: findings from the Minnesota Adolescent Community Cohort (MACC) study. Prev. Med. 54, 242-246. doi:10.1016/j.ypmed.2011.12.029

Green, G., Macintyre, S., West, P., Ecob, R., 1991. Like parent like child? Associations between drinking and smoking behaviour of parents and their children. Br. J. Addict. 86, 745-758.

Henriksen, L., Jackson, C., 1998. Anti-smoking socialization: relationship to parent and child smoking status. Health Commun. 10, 87-101. doi:10.1207/s15327027hc1001_5

Huver, R.M.E., Engels, R.C.M.E., de Vries, H., 2006. Are anti-smoking parenting practices related to adolescent smoking cognitions and behavior? Health Educ. Res. 21, 66-77. doi:10.1093/her/cyh045

Jackson, C., Henriksen, L., 1997. Do as I say: parent smoking, antismoking socialization, and smoking onset among children. Addict. Behav. 22, 107114.

Kyrlesi, A., Soteriades, E.S., Warren, C.W., Kremastinou, J., Papastergiou, P., Jones, N.R., Hadjichristodoulou, C., 2007. Tobacco use among students aged 13-15 years in Greece: the GYTS project. BMC Public Health 7, 3. doi:10.1186/1471-2458-7-3

Martínez-Hernáez, Á., Marí-Klose, M., Julià, A., Escapa, S., Marí-Klose, P., DiGiacomo, S., 2012. [Adolescent daily smoking, negative mood-states and the role of family communication]. Gac. Sanit. SESPAS 26, 421-428. doi:10.1016/j.gaceta.2011.09.030

Mayhew, K.P., Flay, B.R., Mott, J.A., 2000. Stages in the development of adolescent smoking. Drug Alcohol Depend. 59 Suppl 1, S61-81.

Mercken, L., Snijders, T.A.B., Steglich, C., de Vries, H., 2009. Dynamics of adolescent friendship networks and smoking behavior: social network analyses in six European countries. Soc. Sci. Med. 1982 69, 1506-1514. doi:10.1016/j.socscimed.2009.08.003

Moeini, B., Poorolajal, J., Gharghani, Z.G., 2012. Prevalence of cigarette smoking and associated risk factors among adolescents in Hamadan City, west of Iran in 2010. J. Res. Health Sci. 12, 31-37.

Nelson, R., Paynter, J., Arroll, B., 2011. Factors influencing cigarette access behaviour among 14-15-year-olds in New Zealand: a cross-sectional study. J. Prim. Health Care 3, 114-122. 
OECD, 2012. Health at a Glance: Europe 2012. Organisation for Economic Co-operation and Development, Paris.

Otten, R., Engels, R.C.M.E., van den Eijnden, R.J.J.M., 2008. General parenting, anti-smoking socialization and smoking onset. Health Educ. Res. 23, 859-869. doi:10.1093/her/cym073

Otten, R., Harakeh, Z., Vermulst, A.A., Van den Eijnden, R.J.J.M., Engels, R.C.M.E., 2007. Frequency and quality of parental communication as antecedents of adolescent smoking cognitions and smoking onset. Psychol. Addict. Behav. J. Soc. Psychol. Addict. Behav. 21, 1-12. doi:10.1037/0893164X.21.1.1

Petraitis, J., Flay, B.R., Miller, T.Q., 1995. Reviewing theories of adolescent substance use: organizing pieces in the puzzle. Psychol. Bull. 117, 67-86.

Proescholdbell, R.J., Chassin, L., MacKinnon, D.P., 2000. Home smoking restrictions and adolescent smoking. Nicotine Tob. Res. 2, 159-167. doi:10.1080/713688125

Sargent, J.D., Dalton, M., 2001. Does Parental Disapproval of Smoking Prevent Adolescents From Becoming Established Smokers? Pediatrics 108, 1256-1262. doi:10.1542/peds.108.6.1256

Sargent, J.D., Tanski, S., Stoolmiller, M., 2012. Influence of Motion Picture Rating on Adolescent Response to Movie Smoking. Pediatrics peds.20111787. doi:10.1542/peds.2011-1787

Simons-Morton, B.G., 2002. Prospective analysis of peer and parent influences on smoking initiation among early adolescents. Prev. Sci. Off. J. Soc. Prev. Res. 3, 275-283.

Spyratos, D.G., Pelagidou, D.T., Chloros, D., Haidich, A.-B., Karetsi, E., Koubaniou, C., Konstantopoulos, S., Gourgoulianis, K., Sichletidis, L.T., 2012. Smoking among adolescents in Northern Greece: a large crosssectional study about risk and preventive factors. Subst. Abuse Treat. Prev. Policy 7, 38. doi:10.1186/1747-597X-7-38

Vardavas, C.I., Athanasopoulos, D., Balomenaki, E., Niaounaki, D., Linardakis, M.K., Kafatos, A.G., 2007. Smoking habits of Greek preschool children’s parents. BMC Public Health 7, 112. doi:10.1186/1471-2458-7-112 Villanti, A., Boulay, M., Juon, H.-S., 2011. Peer, parent and media influences on adolescent smoking by developmental stage. Addict. Behav. 36, 133-136. doi:10.1016/j.addbeh.2010.08.018

Waldron, I., 1991. Patterns and causes of gender differences in smoking. Soc. Sci. Med. 1982 32, 989-1005.

WHO, 2012. Social determinants of health and well-being among young people. Health Behaviour in School-aged Children (HBSC) study: international report from the 2009/2010 survey (No. No. 6), Health Policy for Children and Adolescents. WHO Regional Office for Europe, Copenhagen. 
WHO, 2013. WHO report on the global tobacco epidemic 2013: Enforcing bans on tobacco advertising, promotion and sponsorship. World Health Organization, Geneva, Switzerland.

Wold, B., Torsheim, T., Currie, C., Roberts, C., 2004. National and school policies on restrictions of teacher smoking: a multilevel analysis of student exposure to teacher smoking in seven European countries. Health Educ. Res. 19, 217-226. doi:10.1093/her/cyg029

\section{Tables}

Table 1: Descriptive statistics for all and by child current smoking status

\begin{tabular}{|c|c|c|c|c|c|}
\hline & & & $\begin{array}{c}\text { Child } \\
\text { smoker }\end{array}$ & $\begin{array}{c}\text { Child } \\
\text { non- } \\
\text { smoker }\end{array}$ & Significance \\
\hline & $\mathrm{N}$ & $\%$ & $\%$ & $\%$ & \\
\hline Ever smoker & 872 & .277 & & & \\
\hline $\begin{array}{l}\text { Current smoker } \\
\text { Cigs in life }\end{array}$ & 850 & .122 & & & \\
\hline A puff to less than 1 cig & 211 & .436 & & & \\
\hline 2 - 25 cigs & 211 & .181 & & & \\
\hline 26 - 99 cigs ( 1 to 5 Packs) & 211 & .091 & & & \\
\hline$>6$ Packs & 211 & .294 & & & \\
\hline Up to 1 cig & 120 & .467 & & & \\
\hline $2-5$ cigs & 120 & .167 & & & \\
\hline $6-20$ cigs & 120 & .225 & & & \\
\hline$>20$ cigs & 120 & .142 & & & \\
\hline Age of first cig & 164 & 13.7 & & & \\
\hline Age & 871 & 14.9 & 16.1 & 14.7 & $* * *$ \\
\hline Male & 869 & .507 & .471 & .501 & \\
\hline School Marks & & & & & \\
\hline $10-13$ & 857 & .051 & .167 & .031 & $* * *$ \\
\hline $13.1-15$ & 857 & .174 & .304 & .151 & \\
\hline $15.1-17$ & 857 & .264 & .324 & .255 & \\
\hline $17.1-20$ & 857 & .511 & .210 & .563 & \\
\hline Cohabit & & & & & \\
\hline Both parents & 871 & .839 & .760 & .859 & $* *$ \\
\hline Father & 871 & .017 & .039 & .015 & \\
\hline Mother & 871 & .057 & .087 & .048 & \\
\hline Other & 871 & .086 & .115 & .078 & \\
\hline Pocket Money & 861 & 45.1 & 73.3 & 40.8 & $* * *$ \\
\hline $\begin{array}{c}\text { At least one parent smokes } \\
\text { Smoking at Home }\end{array}$ & 827 & .484 & 71.1 & 44.8 & $* * *$ \\
\hline Everywhere & 773 & .149 & .289 & .125 & $* * *$ \\
\hline Only in Some areas & 773 & .211 & .237 & .203 & \\
\hline Balcony/yard & 773 & .494 & .330 & .529 & \\
\hline Nowhere & 773 & .146 & .144 & .142 & \\
\hline Antismoking Family Advice & & & & & \\
\hline Never & 701 & .335 & .306 & .338 & ** \\
\hline
\end{tabular}




$\begin{array}{ccccc}1 \text { time } & 701 & .124 & .224 & .109 \\ 2 \text { times } & 701 & .161 & .129 & .166 \\ \text { 3times } & 701 & .379 & .341 & .389 \\ \text { Smoker Friends } & & & & \\ \text { Noone smokes } & 835 & .541 & .100 & .610 \\ \text { Only boys/girls smoke } & 835 & .033 & .050 & .030 \\ \text { At most/least 3 people } & 835 & .372 & .570 & .345 \\ \text { Everybody smokes } & 835 & .053 & .280 & .015 \\ \text { Professional info on smoking } & 857 & .616 & .592 & .624 \\ \text { harms } & & & .940 & .940 \\ \text { Smoking bad for health } & 851 & .937 & .107 \\ \text { Smokers more attractive } & 844 & .137 & .277 & .107\end{array}$

Notes: $* * p<0.05 ; * * * p<0.01$. The last column (i.e. Significance) shows the results of testing for statistical difference in the characteristics between smoking adolescents and nonsmoking adolescents (i.e. column 4 vs column 5). For characteristics that have multiple categories (i.e. School Marks, Cohabit, Smoking at Home, Antismoking Family Advice and Smoker Friends) the test compares and reports statistical differences in the proportions of all categories.

Table 2. Home smoking and antismoking family advice by parental and child smoking

\begin{tabular}{|c|c|c|c|c|}
\hline \multirow[b]{3}{*}{ Home smoking } & \multicolumn{2}{|c|}{ Child Non-smoker (\%) } & \multicolumn{2}{|c|}{ Child Smoker (\%) } \\
\hline & $\begin{array}{c}\text { Parent } \\
\text { Non- } \\
\text { smoker }\end{array}$ & $\begin{array}{l}\text { Parent } \\
\text { Smoker }\end{array}$ & $\begin{array}{l}\text { Parent } \\
\text { Non- } \\
\text { smoker } \\
\end{array}$ & $\begin{array}{l}\text { Parent } \\
\text { Smoker }\end{array}$ \\
\hline & & & & \\
\hline Everywhere & 11.18 & 12.90 & 22.22 & 32.35 \\
\hline Only in some areas & 16.01 & 25.16 & 11.11 & 29.41 \\
\hline Balcony/yard & 56.80 & 49.35 & 51.85 & 25.00 \\
\hline \multirow[t]{2}{*}{ Nowhere } & 16.01 & 12.58 & 14.81 & 13.24 \\
\hline & \multicolumn{2}{|c|}{ p.val $=0.019$} & \multicolumn{2}{|c|}{ p.val $=0.054$} \\
\hline \multicolumn{5}{|c|}{ Antismoking Family Advice } \\
\hline Never & 33.65 & 33.58 & 29.17 & 32.20 \\
\hline 1 time & 11.43 & 10.33 & 16.67 & 23.73 \\
\hline 2 times & 18.73 & 13.65 & 20.83 & 10.17 \\
\hline \multirow[t]{2}{*}{$>3$ times } & 36.19 & 42.44 & 33.33 & 33.90 \\
\hline & \multicolumn{2}{|c|}{ p.val $=0.272$} & \multicolumn{2}{|c|}{ p.val $=0.592$} \\
\hline
\end{tabular}


Table 3. Marginal effects from multivariate analysis results of parental and peer effects on five outcomes of adolescent smoking status

\begin{tabular}{|c|c|c|c|c|c|}
\hline & $\begin{array}{c}\text { (a) } \\
\text { Ever } \\
\text { smoker }\end{array}$ & $\begin{array}{c}\text { (b) } \\
\text { Cigarettes } \\
\text { ever } \\
\text { smoked }\end{array}$ & $\begin{array}{c}\text { (c) } \\
\text { Current } \\
\text { smoker }\end{array}$ & $\begin{array}{c}\text { (d) } \\
\text { Current \# } \\
\text { of } \\
\text { cigarettes }\end{array}$ & $\begin{array}{c}\text { (e) } \\
\text { Age of } \\
\text { first } \\
\text { Cigarette }\end{array}$ \\
\hline Age & $\begin{array}{c}0.037 \\
(3.72)^{* * *}\end{array}$ & $\begin{array}{c}0.052 \\
(2.43)^{* *}\end{array}$ & $\begin{array}{c}0.036 \\
(4.55)^{* * *}\end{array}$ & $\begin{array}{l}0.019 \\
(0.49)\end{array}$ & $\begin{array}{c}0.673 \\
(6.68) * * *\end{array}$ \\
\hline Males & $\begin{array}{l}-0.000 \\
(0.01)\end{array}$ & $\begin{array}{c}-0.151 \\
(2.87)^{* * *}\end{array}$ & $\begin{array}{c}-0.052 \\
(2.45)^{* *}\end{array}$ & $\begin{array}{c}-0.231 \\
(2.71)^{* * *}\end{array}$ & $\begin{array}{l}0.037 \\
(0.13)\end{array}$ \\
\hline Marks (13.1-15) & $\begin{array}{l}-0.095 \\
(1.07)\end{array}$ & $\begin{array}{l}-0.203 \\
(1.82)^{*}\end{array}$ & $\begin{array}{l}-0.098 \\
(1.43)\end{array}$ & $\begin{array}{l}-0.010 \\
(0.07)\end{array}$ & $\begin{array}{l}0.599 \\
(1.34)\end{array}$ \\
\hline Marks (15.1-17) & $\begin{array}{l}-0.158 \\
(1.86)^{*}\end{array}$ & $\begin{array}{c}-0.296 \\
(2.77)^{* * *}\end{array}$ & $\begin{array}{c}-0.159 \\
(2.43)^{* *}\end{array}$ & $\begin{array}{l}0.073 \\
(0.54)\end{array}$ & $\begin{array}{l}0.738 \\
(1.66)\end{array}$ \\
\hline Marks (17.1-20) & $\begin{array}{c}-0.278 \\
(3.31)^{* * *}\end{array}$ & $\begin{array}{c}-0.339 \\
(3.27)^{* * *}\end{array}$ & $\begin{array}{c}-0.234 \\
(3.62)^{* * *}\end{array}$ & $\begin{array}{l}-0.127 \\
(0.75)\end{array}$ & $\begin{array}{l}0.430 \\
(0.82)\end{array}$ \\
\hline Mother in the house & $\begin{array}{l}-0.027 \\
(0.54)\end{array}$ & $\begin{array}{l}-0.158 \\
(1.23)\end{array}$ & $\begin{array}{l}-0.036 \\
(1.00)\end{array}$ & $\begin{array}{l}-0.166 \\
(1.32)\end{array}$ & $\begin{array}{l}0.457 \\
(1.01)\end{array}$ \\
\hline Pocket money & $\begin{array}{c}0.001 \\
(2.48)^{* *}\end{array}$ & $\begin{array}{c}0.001 \\
(2.51)^{* *}\end{array}$ & $\begin{array}{c}0.000 \\
(2.10)^{* *}\end{array}$ & $\begin{array}{l}0.001 \\
(1.41)\end{array}$ & $\begin{array}{l}-0.000 \\
(0.12)\end{array}$ \\
\hline Parents smokers & $\begin{array}{l}0.038 \\
(1.24)\end{array}$ & $\begin{array}{l}0.032 \\
(0.55)\end{array}$ & $\begin{array}{c}0.052 \\
(2.53)^{* *}\end{array}$ & $\begin{array}{c}0.181 \\
(1.96)^{*}\end{array}$ & $\begin{array}{l}0.310 \\
(1.09)\end{array}$ \\
\hline $\begin{array}{c}\text { No restrictions in home } \\
\text { smoking }\end{array}$ & $\begin{array}{c}0.121 \\
(2.64)^{* * *}\end{array}$ & $\begin{array}{c}0.166 \\
(2.24)^{* *}\end{array}$ & $\begin{array}{c}0.071 \\
(2.46)^{* *}\end{array}$ & $\begin{array}{l}0.038 \\
(0.42)\end{array}$ & $\begin{array}{l}-0.380 \\
(1.30)\end{array}$ \\
\hline $\begin{array}{l}\text { Parental anti-smoking } \\
\text { advice } 2 \text { or less times }\end{array}$ & $\begin{array}{l}-0.033 \\
(0.88)\end{array}$ & $\begin{array}{l}0.016 \\
(0.22)\end{array}$ & $\begin{array}{l}-0.001 \\
(0.03)\end{array}$ & $\begin{array}{l}0.089 \\
(1.02)\end{array}$ & $\begin{array}{c}0.767 \\
(2.44)^{* *}\end{array}$ \\
\hline $\begin{array}{l}\text { Parental anti-smoking } \\
\text { advice }>3 \text { times }\end{array}$ & $\begin{array}{l}-0.054 \\
(1.51)\end{array}$ & $\begin{array}{l}-0.044 \\
(0.69)\end{array}$ & $\begin{array}{l}-0.016 \\
(0.63)\end{array}$ & $\begin{array}{l}0.063 \\
(0.63)\end{array}$ & $\begin{array}{c}0.621 \\
(2.05)^{* *}\end{array}$ \\
\hline $\begin{array}{c}\text { Only boys/girls friends } \\
\text { smokers }\end{array}$ & $\begin{array}{c}0.351 \\
(3.64) * * *\end{array}$ & 0.244 & 0.143 & $\begin{array}{l}0.074 \\
(0.42)\end{array}$ & -1.605 \\
\hline Some friends smokers & $\begin{array}{c}0.172 \\
(4.68)^{* * *}\end{array}$ & $\begin{array}{c}0.376 \\
(6.57)^{* * *}\end{array}$ & $\begin{array}{c}0.100 \\
(4.30)^{* * *}\end{array}$ & $\begin{array}{c}0.341 \\
(2.23)^{* *}\end{array}$ & $\begin{array}{l}-0.581 \\
(1.59)\end{array}$ \\
\hline All friends smokers & $\begin{array}{c}0.579 \\
(4.91)^{* * *}\end{array}$ & $\begin{array}{c}0.549 \\
(5.45)^{* * *}\end{array}$ & $\begin{array}{c}0.305 \\
(4.01)^{* * *}\end{array}$ & $\begin{array}{c}0.611 \\
(4.35)^{* * *}\end{array}$ & $\begin{array}{c}-1.332 \\
(2.70)^{* * *}\end{array}$ \\
\hline $\begin{array}{l}\text { Information by } \\
\text { professionals }\end{array}$ & -0.045 & -0.086 & -0.036 & 0.005 & -0.117 \\
\hline Believe smoking harmful & $\begin{array}{c}(1.42) \\
0.113 \\
(1.94)^{*}\end{array}$ & $\begin{array}{l}(1.29) \\
-0.056 \\
(0.38)\end{array}$ & $\begin{array}{c}(1.49) \\
0.066 \\
(2.14)^{* *}\end{array}$ & $\begin{array}{c}(0.05) \\
-0.453 \\
(6.59)^{* * *}\end{array}$ & $\begin{array}{l}(0.44) \\
1.132 \\
(1.50)\end{array}$ \\
\hline $\begin{array}{c}\text { Smokers considered } \\
\text { attractive }\end{array}$ & 0.109 & 0.114 & 0.061 & 0.069 & -0.058 \\
\hline Constant & $\begin{array}{c}(2.15)^{* *} \\
--\end{array}$ & $\begin{array}{c}(1.59) \\
--\end{array}$ & $\begin{array}{c}(1.58) \\
--\end{array}$ & $\begin{array}{c}(0.73) \\
--\end{array}$ & $\begin{array}{l}(0.19) \\
1.443 \\
(0.93) \\
\end{array}$ \\
\hline $\mathrm{N}$ & 689 & 182 & 672 & 106 & 141 \\
\hline
\end{tabular}

Notes: Robust standard errors in parentheses. ${ }^{*} p<0.1 ; * * p<0.05 ; * * * p<0.01$. The first four outcomes

(a) Ever smoker (Yes/No), (b) Cigarettes ever smoked (less or more than one packet), (c) Current smoker (Yes/No) and (d) Current \# of cigarettes (up to or more than 1 cig a day)) are binary and are modelled through logistic regression, while the last one ((e) Age of first Cigarette) is treated as continuous and is modelled through a least squares regression. The coefficients for the first four models are given in marginal effects, while for the fifth model they are the standard OLS coefficients. 


\section{Supplementary material}

Table S1. Multivariate analysis results of parental and peer effects on five outcomes of adolescent smoking status - when at least one parent is a smoker

\begin{tabular}{|c|c|c|c|c|c|}
\hline & $\begin{array}{c}\text { (a) } \\
\text { Ever } \\
\text { smoker }\end{array}$ & $\begin{array}{c}\text { (b) } \\
\text { Cigarettes } \\
\text { ever } \\
\text { smoked } \\
\end{array}$ & $\begin{array}{c}\text { (c) } \\
\text { Current } \\
\text { smoker }\end{array}$ & $\begin{array}{c}\text { d) } \\
\text { Current \# } \\
\text { of } \\
\text { cigarettes }\end{array}$ & $\begin{array}{c}\text { (e) } \\
\text { Age of } \\
\text { first } \\
\text { Cigarette } \\
\end{array}$ \\
\hline Age & $\begin{array}{c}0.033 \\
(2.38)^{* *}\end{array}$ & $\begin{array}{l}0.018 \\
(0.52)\end{array}$ & $\begin{array}{c}0.044 \\
(3.52)^{* * *}\end{array}$ & $\begin{array}{l}0.012 \\
(0.21)\end{array}$ & $\begin{array}{c}0.787 \\
(7.01)^{* * *}\end{array}$ \\
\hline Males & $\begin{array}{l}-0.014 \\
(0.34)\end{array}$ & $\begin{array}{c}-0.252 \\
(3.47)^{* * *}\end{array}$ & $\begin{array}{c}-0.093 \\
(2.78)^{* * *}\end{array}$ & $\begin{array}{c}-0.261 \\
(2.74)^{* * *}\end{array}$ & $\begin{array}{r}-0.045 \\
(0.15)\end{array}$ \\
\hline Marks (13.1-15) & $\begin{array}{l}-0.077 \\
(0.82)\end{array}$ & $\begin{array}{l}-0.140 \\
(1.03)\end{array}$ & $\begin{array}{l}-0.103 \\
(1.63)\end{array}$ & $\begin{array}{l}-0.022 \\
(0.09)\end{array}$ & $\begin{array}{l}0.518 \\
(1.05)\end{array}$ \\
\hline Marks (15.1-17) & $\begin{array}{l}-0.099 \\
(1.10)\end{array}$ & $\begin{array}{c}-0.299 \\
(2.07) * *\end{array}$ & $\begin{array}{l}-0.127 \\
(2.21)^{* *}\end{array}$ & $\begin{array}{l}0.115 \\
(0.55)\end{array}$ & $\begin{array}{c}0.992 \\
(2.01)^{* *}\end{array}$ \\
\hline Marks (17.1-20) & $\begin{array}{c}-0.281 \\
(3.14)^{* * *}\end{array}$ & $\begin{array}{l}-0.232 \\
(1.60)\end{array}$ & $\begin{array}{c}-0.262 \\
(4.41)^{* * *}\end{array}$ & $\begin{array}{l}-0.175 \\
(0.66)\end{array}$ & $\begin{array}{l}0.949 \\
(1.52)\end{array}$ \\
\hline Mother in the house & $\begin{array}{l}-0.006 \\
(0.09)\end{array}$ & $\begin{array}{l}-0.220 \\
(1.41)\end{array}$ & $\begin{array}{l}-0.010 \\
(0.21)\end{array}$ & $\begin{array}{l}-0.272 \\
(1.18)\end{array}$ & $\begin{array}{l}0.003 \\
(0.01)\end{array}$ \\
\hline Pocket money & $\begin{array}{c}0.001 \\
(2.58)^{* * *}\end{array}$ & $\begin{array}{c}0.001 \\
(1.72)^{*}\end{array}$ & $\begin{array}{l}0.001 \\
(1.57)\end{array}$ & $\begin{array}{l}0.001 \\
(1.13)\end{array}$ & $\begin{array}{l}0.001 \\
(0.45)\end{array}$ \\
\hline $\begin{array}{l}\text { No restrictions in home } \\
\text { smoking }\end{array}$ & $\begin{array}{c}0.100 \\
(1.78)^{*}\end{array}$ & $\begin{array}{c}0.287 \\
(3.51)^{* * *}\end{array}$ & $\begin{array}{c}0.083 \\
(2.43)^{* *}\end{array}$ & $\begin{array}{l}0.145 \\
(1.37)\end{array}$ & $\begin{array}{l}-0.479 \\
(1.41)\end{array}$ \\
\hline $\begin{array}{l}\text { Parental anti-smoking } \\
\text { advice }<=2 \text { times }\end{array}$ & $\begin{array}{l}-0.064 \\
(1.09)\end{array}$ & $\begin{array}{l}0.109 \\
(1.05)\end{array}$ & $\begin{array}{l}-0.058 \\
(1.39)\end{array}$ & $\begin{array}{l}0.099 \\
(0.76)\end{array}$ & $\begin{array}{c}0.691 \\
(1.96)^{*}\end{array}$ \\
\hline $\begin{array}{l}\text { Parental anti-smoking } \\
\text { advice }>3 \text { times }\end{array}$ & $\begin{array}{c}-0.101 \\
(2.10)^{* *}\end{array}$ & $\begin{array}{l}-0.036 \\
(0.37)\end{array}$ & $\begin{array}{l}-0.075 \\
(1.95)^{*}\end{array}$ & $\begin{array}{l}0.023 \\
(0.17)\end{array}$ & $\begin{array}{l}0.536 \\
(1.55)\end{array}$ \\
\hline $\begin{array}{c}\text { Only boys/girls friends } \\
\text { smokers }\end{array}$ & $\begin{array}{c}0.389 \\
(3.23) * * *\end{array}$ & $\begin{array}{l}-0.723 \\
(2.36) * *\end{array}$ & $\begin{array}{c}0.177 \\
(2.12)^{* *}\end{array}$ & -0.155 & -1.130 \\
\hline Some friends smokers & $\begin{array}{c}0.182 \\
(4.08)^{* * *}\end{array}$ & $\begin{array}{l}-0.166 \\
(1.71)^{*}\end{array}$ & $\begin{array}{c}0.145 \\
(3.18)^{* * *}\end{array}$ & $\begin{array}{l}0.320 \\
(1.18)\end{array}$ & $\begin{array}{l}-0.448 \\
(1.01)\end{array}$ \\
\hline All friends smokers & $\begin{array}{c}0.585 \\
(3.64)^{* * * *}\end{array}$ & & $\begin{array}{c}0.340 \\
(5.51)^{* * * *}\end{array}$ & $\begin{array}{c}0.558 \\
(2.12)^{* *}\end{array}$ & $\begin{array}{l}-1.109 \\
(1.90)^{*}\end{array}$ \\
\hline $\begin{array}{l}\text { Information by } \\
\text { professionals }\end{array}$ & -0.047 & 0.009 & -0.009 & -0.033 & -0.225 \\
\hline Believe smoking harmful & $\begin{array}{c}(1.01) \\
0.222 \\
(2.37)^{* *}\end{array}$ & $\begin{array}{l}(0.09) \\
-0.438 \\
(1.04)\end{array}$ & $\begin{array}{l}(0.25) \\
0.049 \\
(0.70)\end{array}$ & $\begin{array}{c}(0.29) \\
-0.619 \\
(2.11)^{* *}\end{array}$ & $\begin{array}{l}(0.75) \\
0.293 \\
(0.52)\end{array}$ \\
\hline $\begin{array}{c}\text { Smokers considered } \\
\text { attractive }\end{array}$ & 0.055 & 0.050 & 0.008 & 0.073 & 0.102 \\
\hline & $(0.89)$ & $(0.49)$ & $(0.17)$ & $(0.63)$ & $(0.25)$ \\
\hline Constant & -- & -- & -- & -- & $\begin{array}{l}0.873 \\
(0.51)\end{array}$ \\
\hline $\mathrm{N}$ & 360 & 98 & 348 & 72 & 94 \\
\hline
\end{tabular}

Notes: Robust standard errors in parentheses. ${ }^{*} p<0.1 ; * * p<0.05 ; * * * p<0.01$. The first four outcomes

(a) Ever smoker (Yes/No), (b) Cigarettes ever smoked (less or more than one packet), (c) Current smoker (Yes/No) and (d) Current \# of cigarettes (up to or more than 1 cig a day)) are binary and are modelled through logistic regression, while the last one ((e) Age of first Cigarette) is treated as continuous and is modelled through a least squares regression. The coefficients for the first four models are given in marginal effects, while for the fifth model they are the standard OLS coefficients. 
Table S2. Multivariate analysis results of parental and peer effects five outcomes of adolescent smoking status - when both parents are non-smokers

\begin{tabular}{|c|c|c|c|c|c|}
\hline & $\begin{array}{c}\text { (a) } \\
\text { Ever } \\
\text { smoker }\end{array}$ & $\begin{array}{c}\text { (b) } \\
\text { Cigarettes } \\
\text { ever } \\
\text { smoked }\end{array}$ & $\begin{array}{c}\text { (c) } \\
\text { Current } \\
\text { smoker }\end{array}$ & $\begin{array}{c}\text { (d) } \\
\text { Current \# } \\
\text { of } \\
\text { cigarettes }\end{array}$ & $\begin{array}{c}\text { (e) } \\
\text { Age of } \\
\text { first } \\
\text { Cigarette }\end{array}$ \\
\hline Age & $\begin{array}{c}0.045 \\
(3.15)^{* * *}\end{array}$ & $\begin{array}{c}0.100 \\
(2.52)^{* *}\end{array}$ & $\begin{array}{c}0.034 \\
(3.47)^{* * *}\end{array}$ & $\begin{array}{c}0.130 \\
(1.98)^{* *}\end{array}$ & $\begin{array}{c}0.417 \\
(2.12)^{* *}\end{array}$ \\
\hline Males & $\begin{array}{l}0.018 \\
(0.43)\end{array}$ & $\begin{array}{l}-0.004 \\
(0.04)\end{array}$ & $\begin{array}{r}-0.002 \\
(0.07)\end{array}$ & $\begin{array}{c}-0.635 \\
(2.70)^{* * *}\end{array}$ & $\begin{array}{l}-0.371 \\
(0.54)\end{array}$ \\
\hline Marks (13.1-15) & $\begin{array}{l}-0.067 \\
(0.56)\end{array}$ & $\begin{array}{l}-0.368 \\
(1.83)^{*}\end{array}$ & $\begin{array}{l}-0.001 \\
(0.01)\end{array}$ & $\begin{array}{l}-0.006 \\
(0.03)\end{array}$ & $\begin{array}{l}0.441 \\
(0.59)\end{array}$ \\
\hline Marks (15.1-17) & $\begin{array}{l}-0.168 \\
(1.46)\end{array}$ & $\begin{array}{l}-0.309 \\
(1.62)\end{array}$ & $\begin{array}{l}-0.069 \\
(1.77)^{*}\end{array}$ & $\begin{array}{l}-0.097 \\
(0.26)\end{array}$ & $\begin{array}{l}-0.465 \\
(0.53)\end{array}$ \\
\hline Marks (17.1-20) & $\begin{array}{l}-0.212 \\
(1.91)^{*}\end{array}$ & $\begin{array}{c}-0.425 \\
(2.53)^{* *}\end{array}$ & $\begin{array}{c}-0.120 \\
(3.30)^{* * *}\end{array}$ & $\begin{array}{l}0.383 \\
(1.20)\end{array}$ & $\begin{array}{l}-0.720 \\
(0.85)\end{array}$ \\
\hline Mother in the house & $\begin{array}{l}-0.028 \\
(0.37)\end{array}$ & $\begin{array}{l}-0.164 \\
(0.70)\end{array}$ & $\begin{array}{l}-0.048 \\
(1.16)\end{array}$ & $\begin{array}{l}0.199 \\
(1.04)\end{array}$ & $\begin{array}{l}0.593 \\
(0.72)\end{array}$ \\
\hline Pocket money & $\begin{array}{l}0.000 \\
(0.52)\end{array}$ & $\begin{array}{c}0.002 \\
(2.58)^{* * *}\end{array}$ & $\begin{array}{l}0.000 \\
(0.24)\end{array}$ & $\begin{array}{c}0.003 \\
(2.32)^{* *}\end{array}$ & $\begin{array}{l}-0.005 \\
(0.88)\end{array}$ \\
\hline No restrictions in home smoking & $\begin{array}{c}0.112 \\
(2.07)^{* *}\end{array}$ & $\begin{array}{l}0.028 \\
(0.18)\end{array}$ & $\begin{array}{l}0.023 \\
(0.74)\end{array}$ & $\begin{array}{l}0.059 \\
(0.19)\end{array}$ & $\begin{array}{l}-0.000 \\
(0.00)\end{array}$ \\
\hline $\begin{array}{l}\text { Parental anti-smoking advice } \\
<<=2 \text { times }\end{array}$ & $\begin{array}{l}-0.023 \\
(0.46)\end{array}$ & $\begin{array}{l}-0.026 \\
(0.23)\end{array}$ & $\begin{array}{l}0.048 \\
(1.63)\end{array}$ & $\begin{array}{c}0.578 \\
(1.97)^{* *}\end{array}$ & $\begin{array}{l}0.770 \\
(1.26)\end{array}$ \\
\hline $\begin{array}{c}\text { Parental anti-smoking advice }>3 \\
\text { times }\end{array}$ & -0.007 & -0.092 & 0.030 & 0.819 & 0.872 \\
\hline Only boys/girls friends smokers & $\begin{array}{c}(0.13) \\
0.175 \\
(1.87)^{*}\end{array}$ & $\begin{array}{c}(0.82) \\
0.449 \\
(2.39)^{* *}\end{array}$ & $\begin{array}{c}(0.93) \\
0.120 \\
(1.87)^{*}\end{array}$ & $(2.27)^{* *}$ & $\begin{array}{l}(1.57) \\
-1.877 \\
(0.95)\end{array}$ \\
\hline Some friends smokers & $\begin{array}{c}0.128 \\
(2.92)^{* * *}\end{array}$ & $\begin{array}{l}0.275 \\
(1.59)\end{array}$ & $\begin{array}{c}0.077 \\
(2.60)^{* * *}\end{array}$ & $\begin{array}{l}-0.746 \\
(2.38)^{* *}\end{array}$ & $\begin{array}{l}-0.584 \\
(0.93)\end{array}$ \\
\hline All friends smokers & $\begin{array}{c}0.340 \\
(2.56)^{* *}\end{array}$ & $\begin{array}{c}0.421 \\
(2.27)^{* *}\end{array}$ & $\begin{array}{c}0.126 \\
(2.44)^{* *}\end{array}$ & & $\begin{array}{l}-0.844 \\
(0.93)\end{array}$ \\
\hline Information by professionals & $\begin{array}{l}-0.040 \\
(0.96)\end{array}$ & $\begin{array}{l}-0.181 \\
(1.94)^{*}\end{array}$ & $\begin{array}{c}-0.067 \\
(2.54)^{* *}\end{array}$ & $\begin{array}{l}-0.176 \\
(0.95)\end{array}$ & $\begin{array}{l}0.002 \\
(0.00)\end{array}$ \\
\hline Believe smoking harmful & $\begin{array}{l}-0.003 \\
(0.02)\end{array}$ & $\begin{array}{l}0.213 \\
(1.02)\end{array}$ & $\begin{array}{c}0.199 \\
(3.62)^{* * *}\end{array}$ & & $\begin{array}{l}3.220 \\
(2.44)^{* *}\end{array}$ \\
\hline Smokers considered attractive & $\begin{array}{c}0.130 \\
(2.23)^{* *}\end{array}$ & $\begin{array}{c}0.256 \\
(3.12)^{* * *}\end{array}$ & $\begin{array}{c}0.111 \\
(4.42)^{* * *}\end{array}$ & $\begin{array}{l}-0.162 \\
(0.76)\end{array}$ & $\begin{array}{l}-0.109 \\
(0.20)\end{array}$ \\
\hline Constant & -- & -- & -- & -- & $\begin{array}{l}4.475 \\
(1.40) \\
\end{array}$ \\
\hline $\mathrm{N}$ & 329 & 64 & 324 & 28 & 47 \\
\hline
\end{tabular}

Notes: Robust standard errors in parentheses. ${ }^{*} p<0.1 ; * * p<0.05 ; * * * p<0.01$. The first four outcomes

(a) Ever smoker (Yes/No), (b) Cigarettes ever smoked (less or more than one packet), (c) Current smoker (Yes/No) and (d) Current \# of cigarettes (up to or more than 1 cig a day)) are binary and are modelled through logistic regression, while the last one ((e) Age of first Cigarette) is treated as continuous and is modelled through a least squares regression. The coefficients for the first four models are given in marginal effects, while for the fifth model they are the standard OLS coefficients. 
Table S3. Multivariate analysis results of parental and peer effects five outcomes of adolescent smoking status - for adolescent boys

\begin{tabular}{|c|c|c|c|c|c|}
\hline & $\begin{array}{c}\text { (a) } \\
\text { Ever } \\
\text { smoker }\end{array}$ & $\begin{array}{c}\text { (b) } \\
\text { Cigarettes } \\
\text { ever } \\
\text { smoked } \\
\end{array}$ & $\begin{array}{c}\text { (c) } \\
\text { Current } \\
\text { smoker }\end{array}$ & $\begin{array}{c}\text { (d) } \\
\text { Current \# } \\
\text { of } \\
\text { cigarettes }\end{array}$ & $\begin{array}{c}\text { (e) } \\
\text { Age of } \\
\text { first } \\
\text { Cigarette }\end{array}$ \\
\hline Age & $\begin{array}{c}0.031 \\
(2.17)^{* *}\end{array}$ & $\begin{array}{c}0.076 \\
(1.99)^{* *}\end{array}$ & $\begin{array}{c}0.037 \\
(3.68)^{* * *}\end{array}$ & $\begin{array}{l}0.038 \\
(0.90)\end{array}$ & $\begin{array}{c}0.798 \\
(5.15)^{* * *}\end{array}$ \\
\hline Marks (13.1-15) & $\begin{array}{l}-0.106 \\
(1.26)\end{array}$ & $\begin{array}{c}-0.373 \\
(3.08)^{* * *}\end{array}$ & $\begin{array}{l}-0.062 \\
(1.41)\end{array}$ & $\begin{array}{l}-0.110 \\
(0.80)\end{array}$ & $\begin{array}{l}0.413 \\
(0.74)\end{array}$ \\
\hline Marks (15.1-17) & $\begin{array}{l}-0.188 \\
(2.30)^{* *}\end{array}$ & $\begin{array}{c}-0.401 \\
(3.59)^{* * *}\end{array}$ & $\begin{array}{c}-0.138 \\
(2.98)^{* * *}\end{array}$ & $\begin{array}{l}-0.157 \\
(1.32)\end{array}$ & $\begin{array}{l}0.750 \\
(1.21)\end{array}$ \\
\hline Marks (17.1-20) & $\begin{array}{c}-0.283 \\
(3.60)^{* * *}\end{array}$ & $\begin{array}{c}-0.433 \\
(3.26)^{* * *}\end{array}$ & $\begin{array}{c}-0.141 \\
(3.33)^{* * *}\end{array}$ & $\begin{array}{l}-0.269 \\
(1.16)\end{array}$ & $\begin{array}{l}-0.069 \\
(0.10)\end{array}$ \\
\hline Mother in the house & $\begin{array}{r}-0.005 \\
(0.06)\end{array}$ & $\begin{array}{r}-0.313 \\
(1.31)\end{array}$ & $\begin{array}{l}-0.009 \\
(0.22)\end{array}$ & $\begin{array}{c}-0.415 \\
(2.96)^{* * *}\end{array}$ & $\begin{array}{r}-0.339 \\
(0.54)\end{array}$ \\
\hline Pocket money & $\begin{array}{c}0.001 \\
(2.51)^{* *}\end{array}$ & $\begin{array}{c}0.002 \\
(4.09)^{* * *}\end{array}$ & $\begin{array}{c}0.000 \\
(2.07) * *\end{array}$ & $\begin{array}{l}-0.000 \\
(0.12)\end{array}$ & $\begin{array}{l}0.000 \\
(0.01)\end{array}$ \\
\hline Parents smokers & $\begin{array}{l}0.032 \\
(0.74)\end{array}$ & $\begin{array}{l}-0.027 \\
(0.29)\end{array}$ & $\begin{array}{l}0.021 \\
(0.81)\end{array}$ & $\begin{array}{c}0.189 \\
(1.95)^{*}\end{array}$ & $\begin{array}{l}0.206 \\
(0.50)\end{array}$ \\
\hline No restrictions in home smoking & $\begin{array}{l}0.088 \\
(1.64)\end{array}$ & $\begin{array}{l}0.105 \\
(0.91)\end{array}$ & $\begin{array}{c}0.044 \\
(1.65)^{*}\end{array}$ & $\begin{array}{c}-0.079 \\
(0.71)\end{array}$ & $\begin{array}{c}-0.763 \\
(1.86)^{*}\end{array}$ \\
\hline $\begin{array}{l}\text { Parental anti-smoking advice } \\
<=2 \text { times }\end{array}$ & -0.032 & -0.036 & 0.025 & 0.057 & 1.100 \\
\hline & $(0.60)$ & $(0.28)$ & $(0.79)$ & $(0.42)$ & $(1.98)^{*}$ \\
\hline $\begin{array}{c}\text { Parental anti-smoking advice }>3 \\
\text { times }\end{array}$ & -0.070 & -0.051 & -0.032 & 0.111 & 0.941 \\
\hline & $(1.38)$ & $(0.65)$ & (0.99) & $(0.99)$ & $(1.94)^{*}$ \\
\hline Only boys/girls friends smokers & $\begin{array}{c}0.335 \\
(3.80)^{* * *}\end{array}$ & $\begin{array}{l}-0.150 \\
(1.02)\end{array}$ & $\begin{array}{l}0.100 \\
(1.44)\end{array}$ & $\begin{array}{l}0.010 \\
(0.04)\end{array}$ & $\begin{array}{l}-3.709 \\
(1.95)^{*}\end{array}$ \\
\hline Some friends smokers & $\begin{array}{c}0.126 \\
(2.77)^{* * *}\end{array}$ & $\begin{array}{l}-0.148 \\
(1.38)\end{array}$ & $\begin{array}{c}0.084 \\
(1.92)^{*}\end{array}$ & $\begin{array}{l}0.050 \\
(0.22)\end{array}$ & $\begin{array}{c}-1.097 \\
(1.75)^{*}\end{array}$ \\
\hline All friends smokers & $\begin{array}{c}0.581 \\
(3.18)^{* * *}\end{array}$ & & $\begin{array}{c}0.174 \\
(3.30)^{* * *}\end{array}$ & $\begin{array}{l}0.243 \\
(0.95)\end{array}$ & $\begin{array}{c}-2.025 \\
(2.33)^{* *}\end{array}$ \\
\hline Information by professionals & $\begin{array}{c}-0.035 \\
(0.76)\end{array}$ & $\begin{array}{c}-0.202 \\
(1.86)^{*}\end{array}$ & $\begin{array}{c}-0.004 \\
(0.13)\end{array}$ & $\begin{array}{l}0.073 \\
(0.52)\end{array}$ & $\begin{array}{c}-0.333 \\
(0.84)\end{array}$ \\
\hline Believe smoking harmful & $\begin{array}{l}0.130 \\
(1.25)\end{array}$ & $\begin{array}{l}0.134 \\
(0.95)\end{array}$ & $\begin{array}{c}0.109 \\
(2.43)^{* *}\end{array}$ & $\begin{array}{c}-0.434 \\
(2.53)^{* *}\end{array}$ & $\begin{array}{l}0.564 \\
(0.74)\end{array}$ \\
\hline Smokers considered attractive & $\begin{array}{l}0.006 \\
(0.09)\end{array}$ & $\begin{array}{c}0.266 \\
(3.81)^{* * *}\end{array}$ & $\begin{array}{l}0.006 \\
(0.21)\end{array}$ & $\begin{array}{l}0.186 \\
(1.33)\end{array}$ & $\begin{array}{l}0.505 \\
(1.06)\end{array}$ \\
\hline Constant & -- & -- & -- & -- & $\begin{array}{l}1.398 \\
(0.62) \\
\end{array}$ \\
\hline $\mathrm{N}$ & 343 & 73 & 329 & 55 & 69 \\
\hline
\end{tabular}

Notes: Robust standard errors in parentheses. ${ }^{*} p<0.1$; ** $p<0.05 ; * * * p<0.01$. The first four outcomes

(a) Ever smoker (Yes/No), (b) Cigarettes ever smoked (less or more than one packet), (c) Current smoker (Yes/No) and (d) Current \# of cigarettes (up to or more than 1 cig a day)) are binary and are modelled through logistic regression, while the last one ((e) Age of first Cigarette) is treated as continuous and is modelled through a least squares regression. The coefficients for the first four models are given in marginal effects, while for the fifth model they are the standard OLS coefficients. 
Table S4. Multivariate analysis results of parental and peer effects five outcomes of adolescent smoking status - for adolescent girls

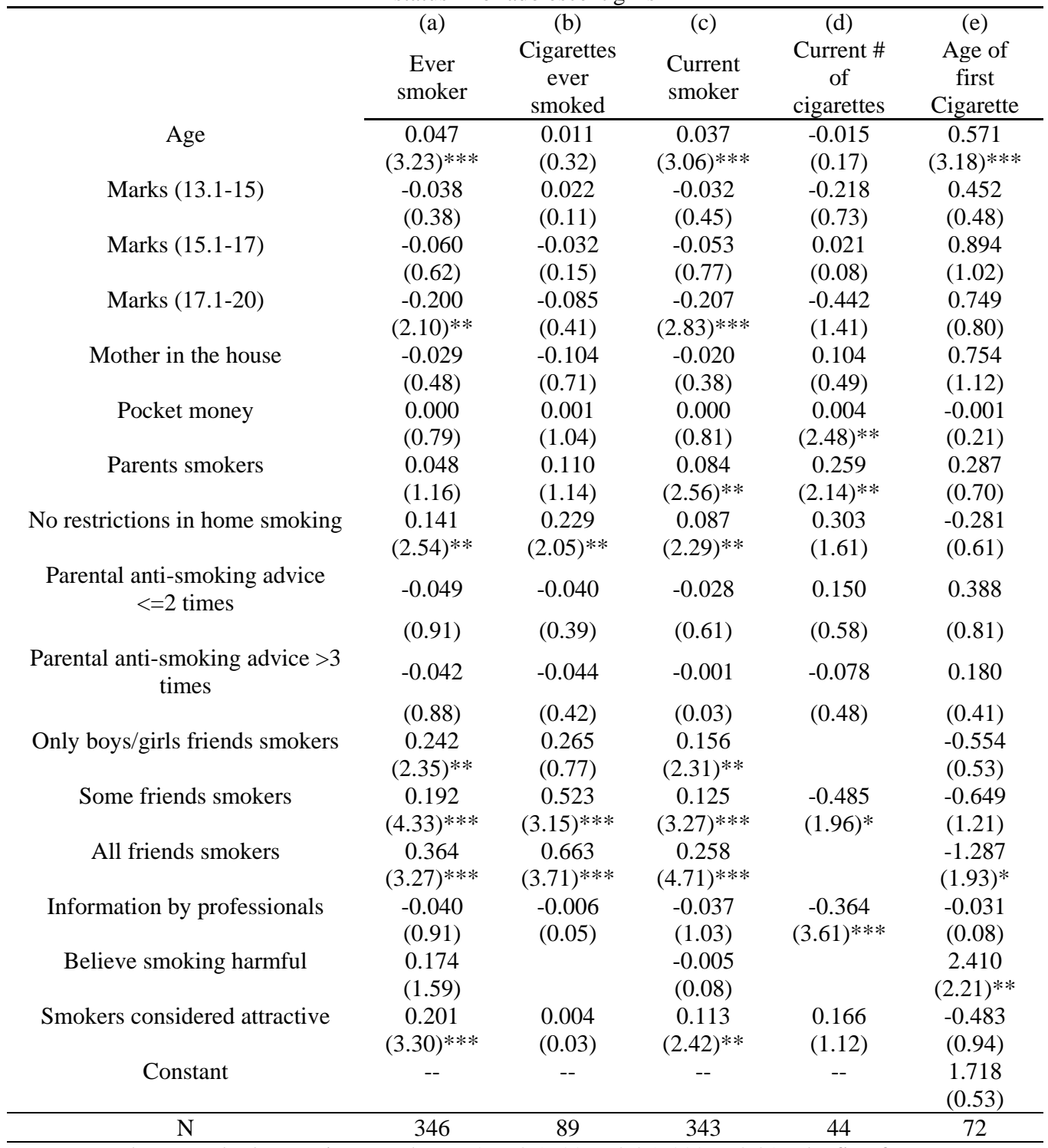

Notes: Robust standard errors in parentheses. ${ }^{*} p<0.1$; ** $p<0.05 ; * * * p<0.01$. The first four outcomes

(a) Ever smoker (Yes/No), (b) Cigarettes ever smoked (less or more than one packet), (c) Current smoker (Yes/No) and (d) Current \# of cigarettes (up to or more than 1 cig a day)) are binary and are modelled through logistic regression, while the last one ((e) Age of first Cigarette) is treated as continuous and is modelled through a least squares regression. The coefficients for the first four models are given in marginal effects, while for the fifth model they are the standard OLS coefficients. 